\title{
OPERATION QUEANBEYAN - OCTOBER 1966: UNFINISHED BUSINESS FROM OPERATION CANBERRA
}

\author{
Max Carroll, Michael Deak (Michael von Berg) \\ and Barry Campbell
}

\section{Editors' introduction}

Clearly, the need for 5th Battalion, the Royal Australian Regiment (5 RAR), to leave the Nui Dinh hills to play its part in Operation Robin left 1st Australian Task Force (1 ATF) with many unanswered questions about follow-up action to the events of Operation Canberra. As described at the end of the previous chapter, Brigadier Jackson understood that 5 RAR, having mounted the previous operation, was already familiar with the terrain and the enemy's tactics and was best suited to conduct a follow-up operation. He quickly endorsed the battalion's obvious desire to attend to what it considered to be unfinished business, and let it get on with the job.

\section{Max Carroll}

Deception was a major factor in our planning for Operation Queanbeyan. We knew that some Viet Cong (VC) were still up on Nui Thi Vai and that the passage of the road convoys would have been observed and reported, 
as would our security activities along Route 15. It was a fair assumption that our fire support base (FSB) location would also have been noted and the volume of traffic associated with it detected. Once the road convoys stopped it would be expected that we would regroup before moving again towards Nui Thi Vai. Time was critical, as we needed to be well clear of the road and concealed in the jungle before the $\mathrm{VC}$ realised we were gone. To this end we planned on approaching along four separate company routes with Battalion Headquarters (BHQ) and its protective Anti-Tank and Assault Pioneer platoons initially following A Company. $\mathrm{B}$ and $\mathrm{C}$ Companies could commence their insertions from their present locations on Route 15, but both A and D Companies had to be relocated from their southern positions. This was done over the last day of the convoy movements, as part of our normal armoured road patrols. D Company of $6 \mathrm{RAR}$, which was to protect our FSB, was inserted among the daily resupply convoys, so there was no obvious increase in our normal traffic movements. We also left our headquarters tents erected so there was no change in the appearance of the base.

Our intelligence assessment was that the best areas for our renewed search would be the western and northern sides of Nui Thi Vai. The general plan therefore was for two companies to search the north-western spur and the uncleared south-western slopes, a third company to cover the northern side, and a fourth company to establish ambushes on the track system further out to the north (these had been found marked on the VC map captured on Operation Canberra).

D Company was to be the furthest north of our subunits, entering the jungle from up near Phu My. They were to lay the ambushes on the approaches and escape routes to the north. B Company was next down the road and tasked to search the northern slopes and area, while A Company was responsible for the central north-western spur. The BHQ Group was to follow the A Company column before proceeding up the spur to the abandoned pagoda, from where it would control the searching companies, while protected by the two Support Company platoons. The pagoda grounds were big enough for a single Iroquois landing zone (LZ), and once secured, a section of our mortars was to be flown in. C Company was to the south of A Company and responsible for searching the uncleared western slopes. 
Before, when writing operation orders, I had regularly used female names as nicknames for areas and features; these names were often of the wives, fiancées, girlfriends, friends or relatives of both myself and other officers of the battalion. However, after the gasping and irreverent expletives I heard uttered by my colleagues, directed at the hill feature Julie during Operation Canberra as we clawed our way up its extreme slopes, I decided it was not a good idea! For Operation Queanbeyan, the nicknames I used for areas were: A Company, Alvenia; B Company, Blanche; C Company, Christine; D Company, Doda; and our headquarters, Heidi. All these names were from Playboy centrefolds adorning many tents at Nui Dat. There were no personal connections, so any sensitive feelings we harboured were protected.

All our columns moved off from their respective harbours along Route 15 at 0300 hours on 17 October 1966, heading eastwards towards their assigned areas. All made good time and were well inside the jungle before halting for a short rest to await the dawn. We, the A Company and BHQ Group column, then followed a track which headed towards our destination, making best possible speed. It was not long before A Company found a large vacated VC camp across our front, which had well-constructed trenches with overhead protection. We were lucky it was not occupied! While checking this area a booby trap was exploded, fortunately without harming anyone, but it could have warned any VC further ahead. We continued carefully until we arrived at an unoccupied group of well-built houses located at the base of the north-western spur. While A Company was securing the area another booby trap was triggered, this time wounding four men, who had to be evacuated. It was obvious that A Company was going to be busy searching the houses and lower slopes for some time after their casualties were evacuated, so the AntiTank Platoon led the BHQ Group up the spur line leading to the pagoda. In places steps had been cut into the mountainside. However, for most of the climb it was very hard going, as our destination was over 430 metres above our start point. 


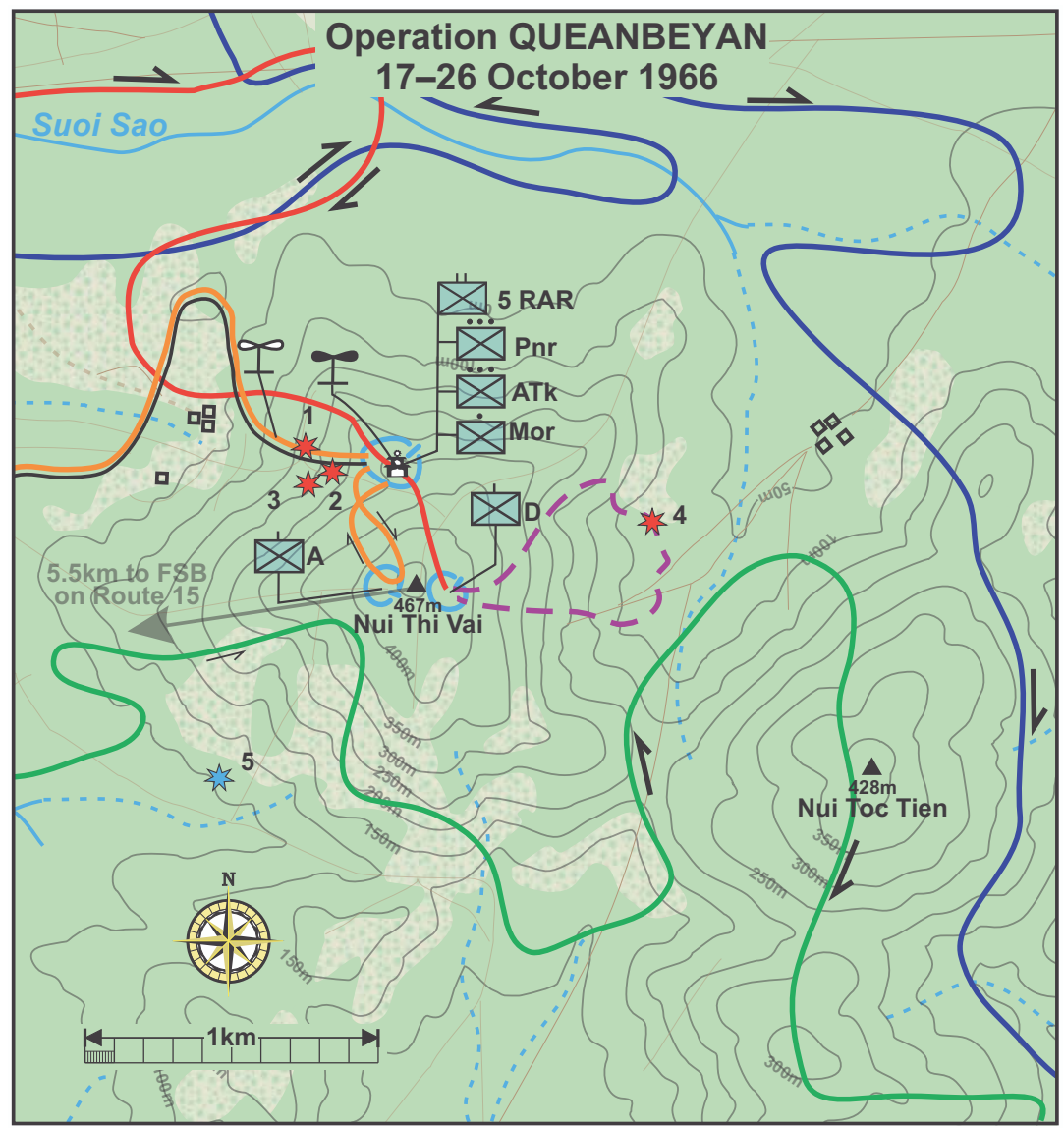

\section{Map 11: Operation Queanbeyan:}

\section{7-26 October 1966.}

Source: Designed by Ron Boxall and produced by Alan Mayne from circa 1966 US military maps provided by Bruce Davies.

\begin{tabular}{|c|c|}
\hline $\begin{array}{c}\text { LEGEND } \\
\text { Operation QUEANBE }\end{array}$ & YAN \\
\hline Defended Locality & \\
\hline Pagoda & 土 \\
\hline Sioux LZ & o \\
\hline Iroquois LZ & T \\
\hline Enemy Contacts & $2^{2}$ \\
\hline BHQ $17^{\text {TH }}$ Oct & 1 \\
\hline ATk Platoon $17^{\mathrm{TH}}$ Oct & 2 \\
\hline Aslt Pnr Platoon $18^{\text {TH }}$ Oct & 3 \\
\hline 10 Platoon $21^{\text {st }}$ Oct & 4 \\
\hline BHQ Axis of Advance & $\longleftarrow$ \\
\hline A Company Axis & $\leftarrow$ \\
\hline D Company Axis & $\leftarrow$ \\
\hline 10 Platoon Route & 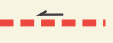 \\
\hline $\begin{array}{ll}\text { Terminology: } & \text { Appendi } \\
\text { Symbols: } & \text { Appendi }\end{array}$ & $\begin{array}{l}\operatorname{lix} E \\
\text { ix } F\end{array}$ \\
\hline
\end{tabular}


The ground was extremely broken, with a steep-sided re-entrant (deep gully) full of boulders and jungle on the right flank, and progress was slow and careful, with the Anti-Tank Platoon clearing the track in tactical bounds until they reached the pagoda. The BHQ Command Group and the Assault Pioneer Platoon had halted further down the track waiting for the radio call from the Anti-Tank Platoon that the track was clear. At this point the BHQ Reconnaissance Party, led by Captain Brian Le Dan, moved off to lay out the area ready for the arrival of our main body. Shortly after their departure several shots were fired from up the track, and their distinctive sounds told us they were not from our weapons! A strong volley of friendly fire followed, then we received a radio call from Brian Le Dan's operator that the Reconnaissance Party was under fire; Brian had been hit and could not get to the radio. The situation had become decidedly unpleasant. At this point it is appropriate to pass the narrative over to Second Lieutenant Michael Deak, as he and his Anti-Tank Platoon had a very busy afternoon. His graphic account, which follows, is a good example of a difficult platoon action.

\section{Michael Deak}

I've never quite understood why I have always had some sort of an attraction for hills and mountains. Was it my time in postwar Austria, living in the Alps, or later after immigrating to Australia, the Snowy Mountains, or nearer to home, Rocky and Willan's Hills near Wagga Wagga? There was a similar, perhaps naive, attraction for the mountain ranges to the west of our defensive position at Nui Dat. After Operation Canberra's first foray onto its rocky, jungle-clad slopes, we were about to reconfront Nui Thi Vai, which peaked at 467 metres and rose very steeply from the surrounding flat terrain.

On our ascent on 17 October the Anti-Tank Platoon, operating as a rifle platoon, was tasked with climbing the north-western spur of Nui Thi Vai to clear the area ahead of the BHQ Group, which intended to establish a command post at the pagoda located below and to the north-west of the summit. After receiving my orders from BHQ, I called my section commanders together to brief them on our mission and, most importantly, the enemy threat. When in Vietnam, many of us often forgot what day of the week it was because we were operating $24 / 7$ and the days' names 
seemed unimportant. But I do remember that the day that we stepped off to climb this mysterious feature was Monday, the start of a working week back in Australia; and what a working week it was to be for the battalion.

I was most fortunate to have very experienced and capable section commanders and, once they had briefed their sections, we slowly headed up a small footpad led by Corporal Allan McLean's section, with my platoon headquarters behind him. Then followed the other two sections led by Corporals Norman Womal and Bill 'Sharpie' Drennan. No more than 15 minutes into the ascent at very slow patrol pace, we were confronted with a steeper climb with a gradient of 1 in 2 . It wasn't so much the gradient that worried us, but the huge outcrops of boulders, rock slides and big trees with root systems intertwined through and around the footpad. These, with the platoon fully laden in hot, humid conditions, made it a very hard climb. It was made more difficult for all of us, with adrenaline pumping and super alert, by having the large re-entrant on our right with boulders and outcrops able to hide an enemy group of any size. Although energy sapping, we managed the climb without incident and I called a halt at the flat ground surrounding the pagoda to await the remainder of the BHQ Group and Assault Pioneers. Then a burst of fire was heard from down the track that we had supposedly cleared. To make matters worse, I heard on our radio that our signals officer, Captain Brian Le Dan, had been wounded in an exchange of fire between enemy and the BHQ Reconnaissance Party. Hearing of Brian's wound, I felt guilty in that we had supposedly cleared the area of enemy where they had been ambushed. These thoughts were rushing through my mind when the commanding officer (CO) ordered me to come back down the track and clear the enemy from above. This I was determined to do!

We were somewhat fatigued from the climb, but I ordered the platoon to drop our heavy backpacks in a pile, which we camouflaged, and took all spare ammunition with us. Corporal Norm Womal's section then led the platoon back down the track with the rest of us following, our descent being a lot faster and easier than the climb up. We approached the area where Brian had been wounded and I got a quick situation report from Warrant Officer Bruce 'Hughie' Hughson, the company sergeant major (CSM) of Support Company, who was close to where Brian was being treated by Captain Tony White, our battalion's medical officer. The information I received was somewhat sketchy as nobody could indicate from where the enemy fire was coming. It was continuing spasmodically from different directions and locations on the opposite side of the re-entrant which had concerned me on the way up. 
Close fire support from artillery or mortars was impractical due to the enemy being so close to us and the nature of the target area, with its many large boulders and trees. We had to resort to covering fire from within the platoon, trying to clear the enemy by conducting fire and movement drills in very difficult terrain down through the re-entrant. In a situation like this there was no opportunity to get the section commanders together for some form of coordination briefing on how we were going to tackle this situation. We were all under fire and any movement without covering fire was very dangerous. I simply had to convey my orders to everyone by shouting what I required to be done, using my loudest parade ground voice; which, thankfully, was clearly understood, even over the continual sound of small arms gunfire. In this sort of situation as a platoon commander you need to shout your orders very clearly. There can't be any misunderstanding or ambiguity. You tell your men what you want and, thankfully, all my men on the mountain that day reacted fearlessly and fought magnificently.

I ordered Corporal Allan McLean's section to be the supporting fire team back up the track where there was a rock projecting out from the footpad, and which had a good view and field of fire down along the re-entrant where we thought some of the enemy were located. Norm Womal's section was to clear the re-entrant, moving by fire and movement from the north-east to the south-west, accompanied by myself, my signaller and our stretcher bearer (medic). My platoon sergeant, Ray 'Skinny' Calvert, was with Sharpie Drennan's section behind us, acting both as my reserve and a covering fire team across the top of the re-entrant as we descended into it. I thought this combination of direct and enfilade fire would give the clearing section enough covering fire. I would call for it when, with each fusillade, Norm Womal and his section, using fire and movement, would advance from cover to cover to try and clear the re-entrant and up its steep other side where we thought the enemy was located. Suddenly there was a burst of enemy fire and Norm shouted 'Skip, I've been hit'. This immediately changed the dynamics of the situation. I had always briefed my men that if they were wounded or dead, we would do everything to get them out. This was now a primary task but, because of the nature of the terrain, none of us knew where Norm was located. Although seriously wounded, he was still shouting orders to his machine gun group and we began to fight our way towards where we had heard him but, soon after, he fell silent. We eventually found that he was lying on a large flat rock. However, we knew the enemy were using Norm as bait because every time 
I or my stretcher bearer, Private Peter Fraser, tried to get to him there was a burst of fire hitting the flat rock where he lay. I simply could not risk anyone crawling out to assist Norm until we had been able to suppress the enemy fire. Not knowing where they were located made this extremely difficult. The enemy fire seemed to be coming from different directions and locations, indicating that it came from more than just a random track watcher. Of concern to me was the obvious fact that the enemy had identified my voice as that of the leader. Every time I shouted an order, fire would come my way, necessitating intuitive and rapid decisions about where to take cover before shouting orders.

This made the recovery of Norm extremely difficult and, contrary to my orders, I saw Peter Fraser, our stretcher bearer, crawling out to Norm to try and treat his wounds. My heart stopped at the thought of needing to extract two wounded soldiers, and the increasing possibility of running short of ammunition really concerned me. The platoon's covering fire somewhat suppressed that of the enemy but there were still bullets hitting the flat rock where both Norm and Peter lay. Then I saw an act of incredible courage, as Peter crawled to place his body between Norm and the enemy to protect him from further wounding. While communicating with Peter, I ordered a maximum amount of covering fire to give Skinny Calvert a chance to work his way to the edge of the rock with a stretcher party to drag Norm up the friendly side of the re-entrant to safety. There a makeshift helicopter landing pad had been organised by BHQ away from enemy fire. It took us almost two hours to extract Norm but, sadly, he died from a gunshot wound to the neck before he could be evacuated to hospital.

The next problem was to extract Norm's section, myself and my signaller from the killing ground. Again using our own platoon's covering fire, we managed to do so while the enemy were still spasmodically firing. It was now growing late in the day and our ammunition was becoming critically low and we were no further advanced. I had lost a good noncommissioned officer and the enemy were still in place and shooting at us, with relative impunity, from the opposite side of the re-entrant. The whole of the BHQ Group were held up on a steep mountain track and I was feeling somewhat desperate and frustrated. So much so that I grabbed an M60 machine gun from one of my gunners and fired a belt of ammunition into the trees on the other side of the re-entrant, thinking the snipers were up in the trees where we couldn't see them. This made me feel better to the point that my head cleared, and I set about making 
'an appreciation of the situation' as I was taught to do in my officer training at the Officer Cadet School just one year ago. How would I get out of this mess? Then over the radio, Major Peter Cole, commanding A Company which was located at the base of a spur some 800 metres away, said that he could see where he thought the enemy were located and could try to neutralise them using some of the M60 machine guns in his company. I had a pretty good idea of the characteristics of the M60 and its beaten zone (size and shape of the area of fall of its multiple projectiles) at a range of 800 metres and, with my platoon still being very close to the enemy, I was not totally enthusiastic, but, being short of ammunition, I agreed, and we marked our locations using coloured smoke grenades. When we were all prepared, A Company opened fire and as soon as I heard rounds cracking over our heads and all around us I gave the order to STOP! My fears about the beaten zone had been correct but in no way was my order to halt A Company's supporting fire a reflection on the help offered by Peter Cole and his company. Serious problems need serious solutions, but this one was not the answer. As the enemy were still taking pot shots, making movement along the track impossible, I received a radio message that the 'cavalry' in the form of a US Army helicopter light fire team was being called in to assist us to clear out the enemy position. This was the best news I had had all afternoon; and the sounds of the two UH1 Iroquois gunships off in the distance ready to support us boosted the morale of everyone on that mountainside.

We again marked our positions using coloured smoke grenades and the choppers came in one after the other to a point where the pilots could see some tunnel openings we had not located and launch their rockets right into the mouths of those tunnels. This went on until all their ammunition and rockets had been expended. Although aware of the devastation that this firepower could cause, I was not sure what results this lot had achieved, if anything at all. I was dreading having to go back down and across that re-entrant where we were ambushed, but an assessment had to be made to establish whether there were any enemy casualties and whether there were more to be dealt with. We noticed that the enemy firing had stopped, and this encouraged us to get on with the job we had been given three and a half hours earlier. I left Allan McLean's section where they had been providing support throughout and, with a small group, slowly cleared from boulder to boulder and other forms of cover that could be used by the enemy. We made our way up the opposite side of the re-entrant without further enemy resistance. After the previous 
three hours this was quite a relief, and what we discovered confirmed why we had no idea of how many and from exactly where the enemy had been shooting at us. We found numerous interconnected tunnels in the rocks, blood-soaked bandages and pieces of equipment. But the area was booby-trapped and, therefore, not within my 'pay scale'. This was a major job for assault pioneers and combat engineers, so I withdrew my platoon and we were ordered to make our way back up to where we had left our heavy packs. We carefully made sure that they had not been discovered and booby-trapped. With that done successfully, we went into a harbour position around the pagoda with the rest of the BHQ Group and the Pioneer Platoon.

Once I had been debriefed I settled down to make a small meal and called my section commanders in to congratulate them on a job well done. I then quietly sat on my own to reflect and consider what had happened that afternoon. I was devastated at losing Norm Womal, an outstanding soldier and human being, married with four children. I did much soul searching then, and still do today, about what I might have done differently. That night I curled myself up in my hutchie and quietly wept. I needed to do that to mourn his loss and enable me to continue in my role with confidence and clarity. Everyone in the platoon on that day fought like men possessed. The way that Norm Womal fought to the end and Peter Fraser's astonishing courage on that rock will stay with me forever. Norm was subsequently awarded a Mentioned in Dispatches posthumously and Peter a Military Medal (MM), one of the few stretcher bearers so recognised. Years later Peter sadly succumbed to motor neurone disease. Before he died, he asked me to deliver the eulogy at his funeral in Perth, where I was honoured to applaud Peter's bravery for the benefit of his many civilian mates. Although recognised by the award of an MM, I still feel that his actions deserved a higher award.

\section{Max Carroll}

I shall backtrack to fill in the activities which occurred while the Anti-Tank Platoon was engaged. The BHQ Reconnaissance Party included the Regimental Sergeant Major, WO1 Les Foale, and the CSM Support Company, WO2 Hughie Hughson. When fired on, they immediately deployed defensively and, under cover of their own fire at suspected VC positions, recovered the wounded Brian Le Dan to 
a safe position from where he could radio the situation to us. He had been very lucky in that the enemy round had struck the safety slide of his Owen gun. The bullet had shattered, with fragments tearing into the right side of his chest inflicting nasty flesh wounds. When we learnt of Brian's wounding, the CO ordered Tony White, our doctor, and an escort to proceed up the track to provide medical treatment and evacuate him. I also called for a Dustoff helicopter to move to our FSB on Route 15 to standby, as there was nowhere at our present location suitable for the large helicopter to extract a casualty.

The prospect of a possible stretcher-carry down the horrendous track between us and A Company prompted a search of our area for a place nearby where it might be possible to land a Sioux light observation helicopter, so that he could be quickly extracted and transferred to the waiting Dustoff. Fortunately, there was a large flat rock overhang close by and the Pioneers rapidly removed some trees to enlarge the clear area. Even then there was only one line of approach for the Sioux and the pilot would need to reverse out as there was no room for him to turn the aircraft around on the rock. The flying skills needed to execute this extraction are difficult to describe. Second Lieutenant Bob Askew, who was well known to us, performed this extremely difficult feat of flying with amazing skill.

The serious firefight was still going on a short distance up the spur line and the possibility of enemy fire being directed at the Sioux was very real. Captain Bob Supple from our BHQ Group guided the Sioux's approach while kneeling, as the slope of the ground was such that he could have been decapitated by the rotor blades if standing. Bob Askew gently brought his aircraft in with doubtful clearance for his rotor blades on each side (his account is in Chapter 14). As Brian was 'walking wounded', he was strapped inside the cockpit next to Askew who very carefully lifted off from the rock shelf, reversed his aircraft until he had room to turn, then flew down the mountain to the waiting Iroquois Dustoff. Later in the afternoon, when we needed to extract Norm Womal's body, Askew was called back to do it all again. The Australian Army's 161 (Independent) Reconnaissance Flight pilots who supported us in operations were excellent, often demonstrating a combination of superb flying skills and fearless commitment.

It was late afternoon before the BHQ Group was able to proceed uphill to the pagoda, and ours was very careful movement, with everyone supremely alert. I was feeling uncomfortable, as this was the first operation where 
I had been without my rifle. I had always carried an SLR (self-loading rifle) as well as my $9 \mathrm{~mm}$ pistol, much to the amusement of the CO, who had often teased me saying that we were well protected, and our job was to control the battalion. But now BHQ had been ambushed! Second Lieutenant John McAloney, the Assault Pioneer Platoon commander, had earlier damaged his SLR and it was with our armourer for repair, so I had loaned him mine. Now, here I was travelling up a narrow track between two clearly recognisable radio operators, with a map in my hand and armed with a useless pistol. Anyhow, we duly arrived at the pagoda and established our defensive position just on last light. It had been a long hard day for us, but I was told later that there were some jokers in the rifle companies who found delight in BHQ's discomfiture. On the plus side, it seemed we were no longer regarded as pogos!

After a tense night - the VC were certainly aware of our location - on the morning of 18 October 1966 we dispatched an Anti-Tank Platoon patrol to check out the peak of Nui Thi Vai, which was about 500 metres further uphill from the pagoda. On their return with nothing to report, a section of our mortars was flown in from the FSB on Route 15, and the assault pioneers were warned to be ready to move back down the track to clear booby traps from the tunnels and caves from which we had been ambushed. This was necessary before more detailed searching could be undertaken. From our recent experiences, we anticipated that more combat engineer support would be needed, in addition to their twoman mini-teams that were already attached to each rifle company. To this end, three combat engineer officers flew in as observers to accompany our assault pioneers on their initial cave clearance to assess the requirement for additional men and equipment. By the time this activity was completed it was early afternoon.

While the Support Company platoons were busy, the rifle companies were also proceeding carefully with their allotted tasks. A Company was searching the lower slopes of the north-west spur, B Company was doing the same to the north and D Company was in ambush positions on the northern tracks. Meanwhile, C Company's activities on the south-western slopes made for an interesting day.

On the morning of 18 October 1966, C Company needed combat engineer assistance to complete the demolition of installations started during Operation Canberra. A Royal Australian Air Force (RAAF) Iroquois was therefore tasked to fly in two combat engineers and 
a quantity of explosives to the LZ, which C Company had successfully used twice before on 8 October 1966 when a US Army Iroquois had evacuated their casualties without any problems. C Company were securing the LZ for the RAAF aircraft and some of its members witnessed the disaster which followed. The RAAF Iroquois crashed while trying to land. The RAAF version of the incident and accounts by army witnesses differ. George Odgers, in his book Mission Vietnam, Royal Australian Air Force Operations 1964-1972, states:

When the helicopter reached the 5th Battalion position and hovered over the landing zone, Flight Lieutenant Cliff Dohle decided that the area was too small to land safely so he commenced an overshoot. A few seconds later the aircraft crashed into the jungle and caught fire. Flight Lieutenant Cliff Dohle had managed to warn the crew before the aircraft entered the trees, enabling them to brace themselves to a reasonable extent. ${ }^{1}$

Another account attributed the crash to engine failure, but the C Company witnesses believe that, while hovering, the tail rotor might have clipped a tree. The aircraft came down some 70 metres past the LZ, which seemed like the pilot was having difficulty in controlling a damaged aircraft. Cliff Dohle was a good and courageous pilot, known in the Task Force as the captain of one of the two RAAF 9 Squadron choppers which executed the hazardous ammunition resupply of D Company, 6 RAR, at the Battle of Long Tan. Thankfully, there were no fatalities in this crash. Lieutenant Roger Wainwright, whose 8 Platoon soldiers were nearby and appeared rapidly on the scene to assist, describes the rescue of the aircraft's occupants in Chapter 8.

Before leaving this accident, a couple of observations are warranted. First, I cast no aspersions on RAAF aircrew, having flown with them often during my tour of duty. Having experienced the aggressive, getthe-job-done approach of US Army helicopter support, we naturally felt that RAAF policies on aircraft safety were unrealistic in Vietnam operations and might have influenced Cliff Dohle's decision to abort the landing. There had been much debate with RAAF commanders in the early months of 1 ATF's deployment about helicopter support in ground operations. We had no concerns about the aircrews, who were obliged to abide by RAAF policy constraints and were as frustrated as

1 George Odgers, Mission Vietnam, Royal Australian Air Force Operations 1964-1972, Australian Government Publishing Service, Canberra, 1974, p 34. 
we were. The LZ had been successfully used twice on 8 October 1966 for evacuation of C Company casualties by a US Army Dustoff Iroquois, so we naturally opted to use it again. Also, we considered it unusual that the RAAF crash investigators never interviewed Roger Wainwright, who was present and witnessed the crash, or his soldiers who played a major role in rescuing the copilot and helping others at the crash site. Inability at higher levels to resolve differences between the army and the RAAF on inter-operational matters inevitably led to comparisons between RAAF and US Army helicopter support, and caused unneeded, unnecessary and regrettable tensions between battlefield partners.

The two 8 Platoon soldiers Bill Cavanagh and Syd Shore had saved the copilot, Flight Lieutenant Peter Middleton, at significant risk to themselves. Their actions had been witnessed by Roger Wainwright and his recommendations for awards were successful, with them both being Mentioned in Dispatches. The RAAF crewman, Sergeant Gordon Buttriss, was cited by the RAAF and received the higher award of the George Medal. His citation describes how, after being involved in the crash and getting clear of the wreckage, he twice re-entered the burning aircraft to extricate the two injured army combat engineers, Sapper Dennis Schubert and Sapper Colin Hopper. ${ }^{2}$

To return to the demolition of the VC installations: at 1400 hours on 18 October, Second Lieutenant John McAloney and his party departed the pagoda for the caves and tunnels they were to investigate and clear of any booby traps. The patrol numbered 24 and consisted of McAloney, his signaller, a medic, two understrength sections of assault pioneers, two guides from the Anti-Tank Platoon and three engineer officer observers and their signaller.

They arrived at the cave area at 1440 hours after a careful approach, being very aware that a day had elapsed since the ambush and the VC might have reoccupied the site. Having posted sentries along the track and the remainder of the patrol in covering fire positions, McAloney, his signaller and a single Pioneer cover-man were led up to the cave site by the two AntiTank Platoon guides. He then posted the two guides as sentries above the first cave. He positioned his cover-man, Private Gordon D'Antoine, just

2 RAAF personnel records are stored in 'RAAF Personnel files - All Ranks', National Archives of Australia, A12372. In addition, see 'News of the award of the George Medal to A21702 Sergeant (Sgt) Gordon Dudley Buttriss, of Sefton ...', 1967, Australian War Memorial, VN/67/0020/04, available at: www.awm.gov.au/collection/VN/67/0020/04/. 
forward and downhill of the cave so that he could overlook the immediate area. The signaller remained under cover close by his platoon commander. John then commenced his search for booby traps and discovered the first one, just to the side of a cave entrance below a large rock. He was lowering himself down to look at it when a shot was fired. D'Antoine shouted that the round, which had passed close to him, had come from below and behind him from another cave entrance. John's signaller also reported that the shot had come from below the rock on which he was positioned. John then ordered his fire support group to cover the suspect area, but another shot fired from the same area below hit D'Antoine in the back, apparently from a range of only several metres.

The time between the two shots was about 45 seconds. John then ordered his M60 machine guns to fire into the area below D'Antoine's position, which was also just below his and his signaller's positions. After the first few bursts he had to call for the fire to cease as ricochets off the rocks were passing too close to him. Corporal Brian Burge, commanding the fire support group, fired a snap shot with his SLR from 20 metres at a VC face he saw peering out of a rock hole below McAloney. Burge was certain he hit his target and McAloney and his signaller heard tumbling sounds coming from the rocks beneath them. John then ordered fire into all caves and holes while he and the medic, who had moved forward with difficulty, recovered D'Antoine who had been very badly wounded and died shortly afterwards. At BHQ we had been monitoring the action and organised a platoon from A Company to secure an extraction LZ some way downhill and John sent a stretcher party of four and a protection party of six to evacuate Gordon D'Antoine's body.

About mid-afternoon John and the remainder of his patrol were able to go after the VC. Their first step was to get gas grenades into all tunnels and holes and into the entrance of the main cave. The uphill anti-tank sentries reported no resulting sounds or movement from potential rear exits, so $40 \mathrm{~mm} \mathrm{M79}$ grenades were fired into the cave mouth. John then requested flame-throwers be brought forward; but this entailed a delay of 30 minutes. The A Company platoon securing the extraction LZ was ordered to hold the Assault Pioneer party escorting D'Antoine's body at the LZ, in order to wait and return to John with the flame equipment when it was air delivered. This they did, arriving back at the cave site as it was growing dark. In the meantime, John had been slightly wounded while he was recovering D'Antoine's M16 rifle. He had been unable to reach it earlier when he and his medic were dragging the wounded man 
to safety. The flame-thrower equipment included eight gallons of fuel, some of which was used to saturate suspect holes around the main cave. With covering fire from his support section, John then led a frontal assault at the cave in which the flame-thrower was used to good effect. Flame and smoke were seen billowing out of some probable rear exits. By then fading light prevented any immediate follow-up action, so the patrol reassembled on the track and made good time moving back to the pagoda.

On the next day, 19 October, the assault pioneers returned to the cave area and found that the flame had been effective on the top level. However, this complex consisted of three levels, was overall about 16 metres deep and was large in volume, having some sections with wooden flooring. Seven backpacks which contained good information about the enemy were found and it was clear that the VC had been using this area for some time. The Pioneers continued their search in other caves, finding 60 kilograms of TNT and some grenades, both of Chinese origin, some small antitank rockets and a quantity of documents. During the search they lost two soldiers, Privates Trevor Lynch and David Goodman, wounded by a Chinese directional mine rigged as a booby trap. Trevor Lynch was shockingly wounded, losing both eyes as well as sustaining multiple fragmentation wounds to his head, body and limbs. It was surprising that he survived. After lengthy treatment in Vietnam until well enough, he was evacuated to Australia. The medic Corporal Ian McDougall's gripping account of the incident in which Trevor Lynch suffered his wounds is in Chapter 13.

The whole area that 5 RAR was searching was honeycombed with booby trapped caves and tunnels; and dealing with this situation required very steady nerves and extreme care. All soldiers, both those of the battalion and our supporting sappers (combat engineers), displayed both qualities together with exemplary courage. On this day, B Company on the northern slopes also encountered a group of five $\mathrm{VC}$ local guerrillas, wounding two before the group broke contact and fled. C Company on the western slopes later found and destroyed a cache of two tons of rice. 


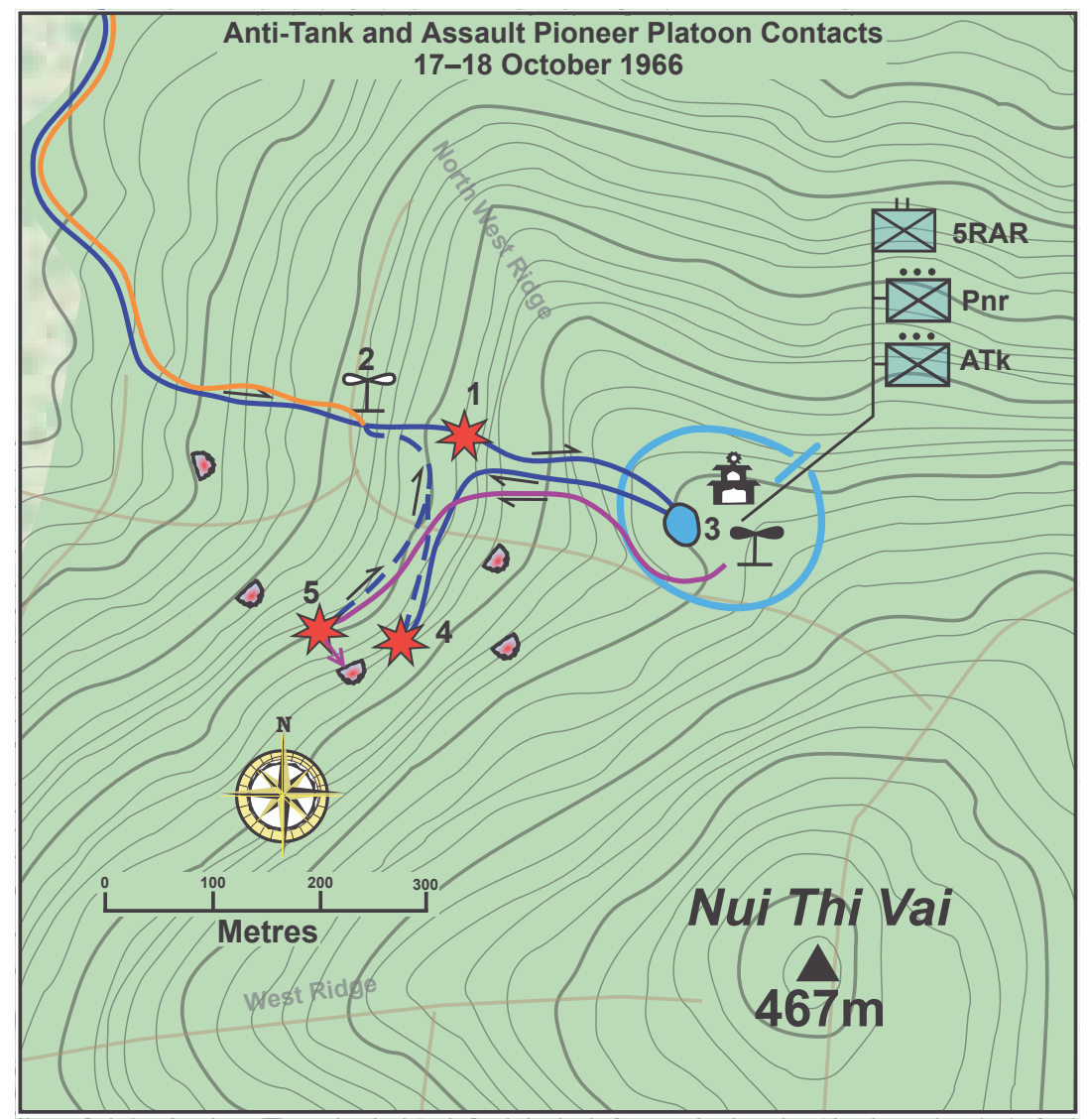

\section{Map 12: Anti-Tank and Assault Pioneer Platoons enemy contacts: 17-18 October 1966.}

Source: Designed by Ron Boxall and produced by Alan Mayne from circa 1966 US military maps provided by Bruce Davies.

LEGEND
Anti-Tank and Assault Pioneer Platoon
Contacts
BHQ Contact
Casevac LOH LZ
ATk Platoon Back Pack Dump
ATk Platoon Contact
Asit Pnr Platoon Contact
Pagoda
Sioux LZ
Iroquois LZ
Enemy Contacts
Cave Complex
Defended Locality
ATk Platoon Route
AsIt Pnr Platoon Route
Aslt Pnr Platoon Cave Assault
Casualty Evacuation Route
Terminology:
Symbols: Appendix E Fendix F




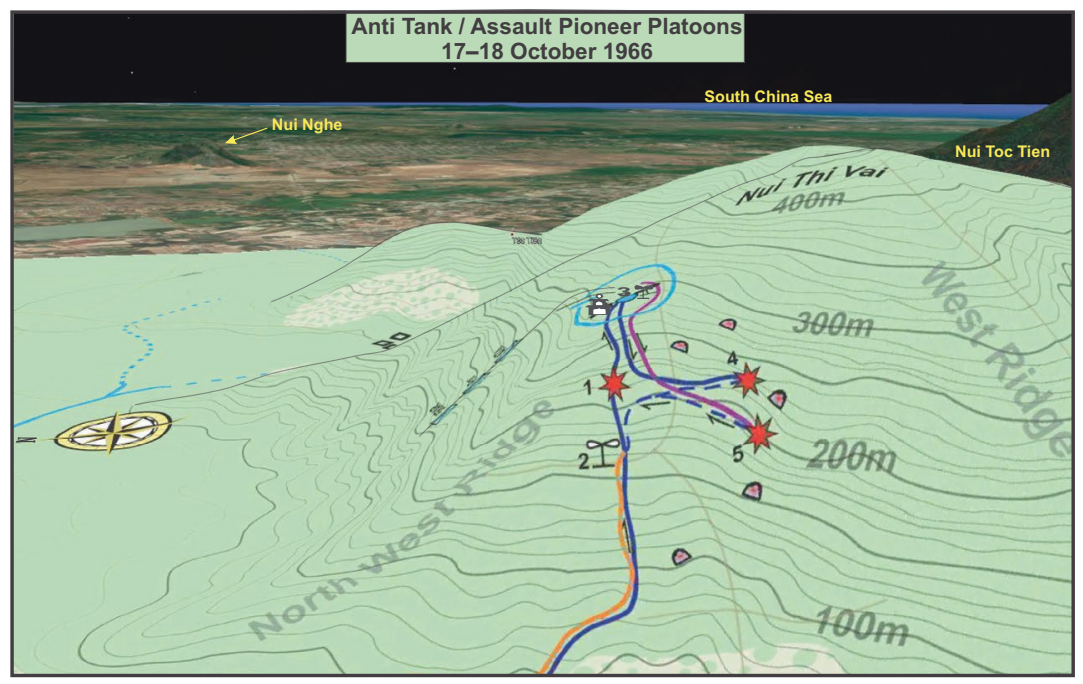

Map 12A: Anti-Tank and Assault Pioneer Platoons enemy contacts: 17-18 October 1966.

Source: Designed by Ron Boxall and produced by Alan Mayne from circa 1966 US military maps provided by Bruce Davies.

Over the following days, further engineer elements and stores were flown in to support us and our successes increased. A Company found, searched and destroyed some booby-trapped cave and tunnel complexes, recovering a variety of documents, training pamphlets and medical supplies including 200 phials of morphine and other drugs. There were also medical certificates from a doctor located in Ba Ria. Undoubtedly, he soon received a nasty visit from the provincial authorities. Apart from this, also found were various kinds of ammunition, stores and equipment, including some anti-tank mines and detonators, webbing and helmets, cooking oils, fish, rice, some paper money and, interestingly, some sets of clean and well-pressed civilian clothes. The most important find was a Chinese military radio transmitter/receiver, complete with its power plant, aerials, Morse key, operating instructions book, log books and other documents. With the radio was a diary belonging to Colonel Nguyen Nam Hung, the deputy commander of 274 Regiment, which provided invaluable intelligence material. The VC must have been in desperate haste to escape to abandon such essential items, even though they were well hidden. B Company discovered and destroyed a well-constructed water point, which had been hollowed out of the rock, and several multiplecompany installations spread over large areas including a facility that had been used as a hospital. C Company found another large camp containing 
some huts, another cache of two tons of rice and a pen holding a sow and her litter of piglets. D Company was relieved of their ambush role by B Company and, on 21 October 1966, redeployed to search the eastern slopes of Nui Thi Vai.

On the afternoon of 21 October 1966, 10 Platoon of D Company, commanded by Second Lieutenant Dennis Rainer, was tasked to investigate any tracks in the saddle area between Nui Thi Vai and Nui Toc Tien, the hill complex further to the east. They found a well-used track leading uphill towards the Nui Thi Vai peak and followed it. They passed through an area that had been napalmed. Rainer halted his leading section to secure against any enemy movement down the main track while he investigated a small side track. This search revealed a sizeable rice cache and he was in the process of quietly destroying it when, by silent signal from his leading section on the main track, he was summoned forward. Initially Lieutenant Barry Campbell, the artillery forward observer with D Company, who was accompanying 10 Platoon on this patrol, went forward to investigate. Barry now takes up the narrative to give a firsthand account of the events that followed.

\section{Barry Campbell}

On 20 October 1966, D Company, to which I was attached as the artillery forward observer, ascended to the summit of Nui Thi Vai and occupied its rock-strewn crest. On the following day 10 Platoon, commanded by Second Lieutenant Dennis Rainer, was tasked to descend the eastern side of the feature to search the area of the pass separating Nui Thi Vai and Nui Toc Tien. I suggested that I should accompany the platoon to ensure that, if needed, they could be provided with fire support; and the OC D Company, Major Paul Greenhalgh, gave me the OK.

We descended several hundred metres to the east and proceeded parallel to a track while contouring the eastern face of Nui Thi Vai in a northerly direction. This route enabled us to cross the lower reaches of any re-entrants (gullies) on the eastern slopes of the mountain. At around 1400 hours, the platoon's leading section found a distinct track leading into a steep and narrow re-entrant. As we followed it uphill into the fissure we detected the distinct smell of smoke, scented with the aroma of cooking bamboo shoots. Clearly a VC encampment of unknown size was very close nearby. 


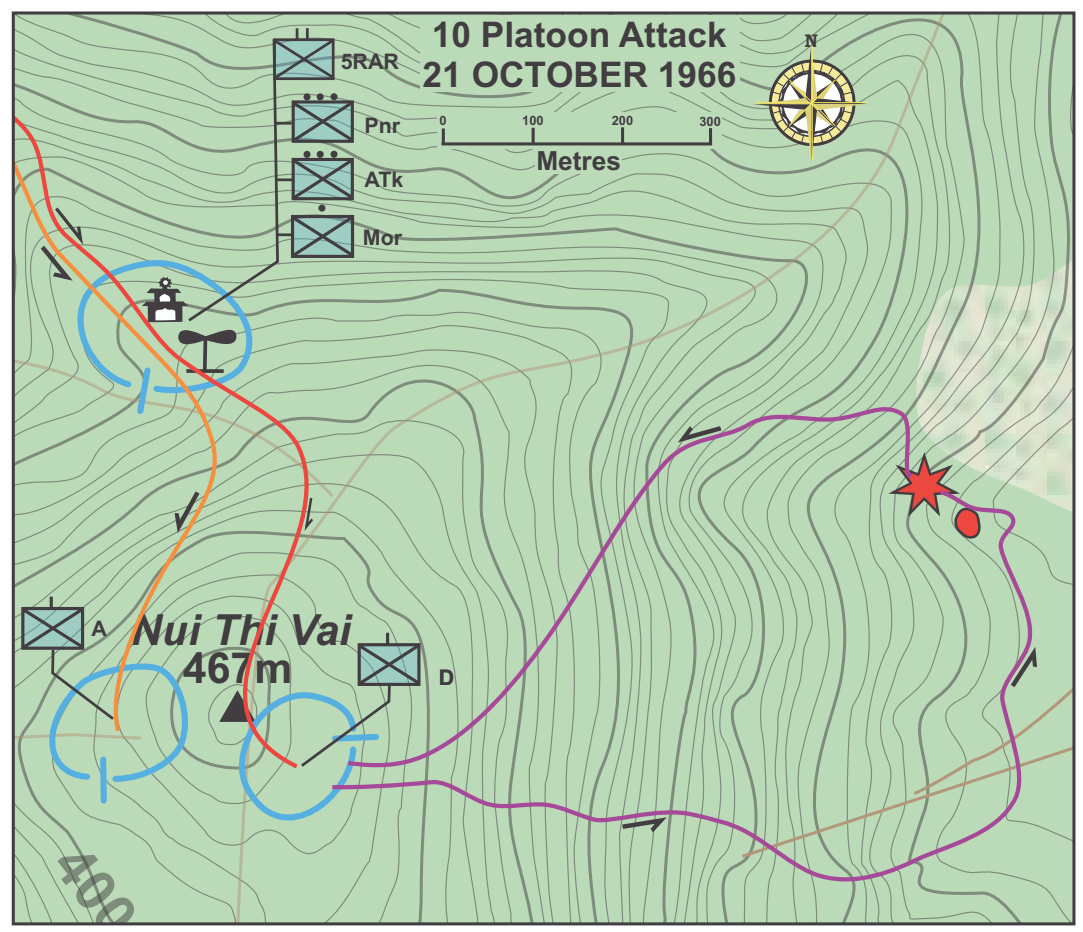

Map 13: 10 Platoon attack: 21 October 1966.

Source: Designed by Ron Boxall and produced by Alan Mayne from circa 1966 US military maps provided by Bruce Davies.

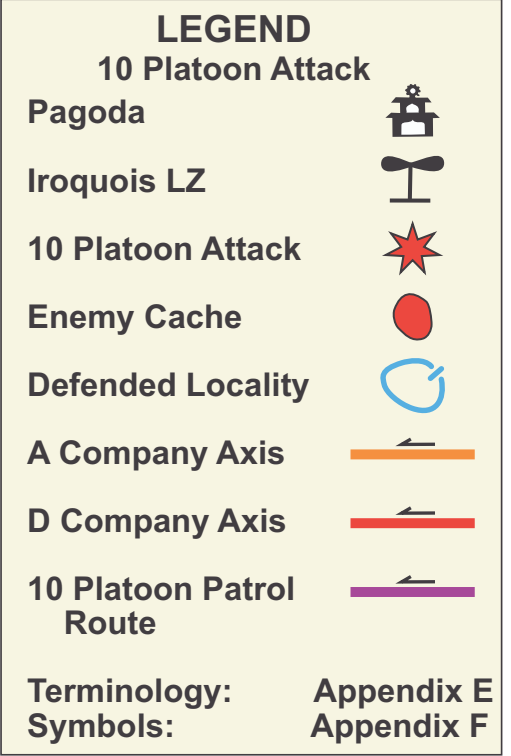


As we silently and carefully followed the track uphill, we came across a large, dry cavern which contained a substantial cache of equipment, food and ammunition. Dennis busied himself with a search of the cache and we received the urgent hand signal message 'fetch officer' from our leading section. Passing the message to Dennis, I moved further forward and came across what was clearly an unoccupied sentry post. Within a short distance I met Corporal Dave Babbage and his great mate and 2IC, Lance Corporal Gary Leslie. They led me to the edge of what was obviously an area cleared of foliage to provide a defensive arc of observed fire. On the other side of this cleared area was a perimeter fence with a sign-posted gate to our left front. The gate's sign had a large skull and cross bones and a depiction of exploding mines or booby traps indicating their presence in the barrier obstacle which extended across the re-entrant. Beside the sign was a makeshift gong comprised of an artillery shell case and a metal striker, presumably for visitors to announce their arrival. We elected to forego such social niceties! Both ends of this barrier abutted the steep rock-faced sides of the re-entrant. The left rock face (to the south) was fronted by a fast-flowing mountain stream. Beside the stream a path led uphill to two huts from which smoke was issuing and dispersing under the heavy overhead tree canopy.

As we took in details of the scene before us, a monsoonal downpour started and under the cover of its noise I examined the mined barrier and found it to be heavily sewn with punji stakes, which were more numerous against the right (northern) side of the re-entrant (punji stakes were short wooden or metal stakes which had been pointed at one end and the other pushed into the ground so that an unwary foot could be impaled). Clearly there was not a second to lose and, on the shaky assumption that the area of thickest punji stakes probably contained fewer mines, I indicated to Babbage and Leslie that I should be followed by each man stepping into my footprints as we traversed the barrier.

It only took a few minutes to cross because the punjis were now set in deluge-softened soil and were easily pushed aside with a foot. Thus, in single file, we passed through the barrier, clambered up the right-hand escarpment and debouched onto the northern side of the encampment. A higher, rocky platform lay above us, so we deployed onto it and awaited Dennis's arrival. So far, so good! Dennis joined us and, with his wonderful eye for ground, indicated that he wished to get further into the re-entrant. For my part, I quickly recognised that the encampment was almost impervious to artillery and mortar fire from the south-west where 
our guns were sited. Two Army of the Republic of Vietnam (ARVN) $105 \mathrm{~mm}$ guns were located to the north-west but were an unknown quantity in terms of their proficiency and familiarity with our procedures. My assessment of the encampment's difficulty as an artillery target was subsequently borne out.

The area higher up into the re-entrant was still unknown to us but, with the benefit of surprise, Dennis thought that initiating an attack from that flank would stand a good chance of flushing the occupants downhill into the fire of the two sections he had deployed on the north side of the re-entrant, overlooking the two huts so far detected. He accepted my offer to lead this activity and with my loyal signaller, Gunner 'Midge' Rogers and Corporal Bob Ziemski's section we proceeded further up the re-entrant. As we carefully climbed up along the re-entrant's rocky northern side it became steeper and we shortly came upon a third hut which was brilliantly sited under almost complete protection by a huge projecting rock slab and backed hard up against a 4-metre-high rock face. The hut was open-sided and from our right a clearly defined track crossed our front and entered the northern end of the structure. Moving carefully, we became aware of one and then a second trip-wired US .30 calibre Garand rifle, both of which were loaded and set to warn of any approach along this track from the north. This hut was clearly the 'command post' of the encampment.

Bob Ziemski and I were crouched about 2 metres from the north end of the open-sided hut and concealed by quite thick foliage. Through the downpour we could see three VC sitting and standing at benches arranged inside the structure. At the southern side of this hut was an exit path which turned sharp left before a 4-metre cliff face and, by means of two small wooden bridges, crossed the stream which, by now, was noisily in full spate due to the continual downpour. Paralleling the stream, the path continued down to the sign-posted entry gate. Taking great care to avoid the booby-trapped rifles, we positioned Bob Ziemski's M60 machine gun team and most of his section on higher ground to our right, so they could cover us from above by firing into the lower two huts.

While this was occurring, Dennis deployed his second and third sections under Dave Babbage and Corporal Bob Bunting, together with his platoon headquarters, to cover the encampment from above and to the north of it. Here they would wait for the attack to be initiated by Bob Ziemski's section, which Midge Rogers and I were accompanying. Bob and I addressed ourselves to dealing with the three occupants of the 
'command post' hut, which we agreed would be the best way to trigger the attack. The nearest occupant appeared to be the senior of the three and was seated with a US .30 calibre M1 carbine on the bench by his right hand. The next VC was towards the middle of the hut and standing while he carefully wiped a rag over a US M3A1 45 calibre 'grease gun' mounted with a long, 30-round magazine. The third man was at the far end of the hut working on some poster artwork, with his rifle to his right leaning against the hut exit. By silent hand signals Bob and I agreed that I would deal with the two closest men and he would handle the third.

Time was racing on, so we both stood upright and, in accordance with the current 'rules of engagement', I called three times for the VC to 'chieu hoi' (surrender)! Such was my nervous tension that the first challenge came out as a girlish squeak. No matter - my sounds were enough to warn Dennis that the assault he was commanding was commencing! To their great credit the three $\mathrm{VC}$ we confronted reacted with boldness and defiance; it was only the element of surprise that gave Bob and me the crucial advantage that we needed. I dealt with the middle man first because he was holding a weapon. However, he still managed to fire two rounds, which went through the thatched roof and into the rock overhang above the hut. The closest VC reacted instantly but the need to reach for and aim his rifle proved fatal. His movement obscured Bob's view of the furthest man who fled out of the far end of the hut but, when he turned left to cross the first bridge, Bob and I fired at him simultaneously. In seeking his target, Bob had moved to my left side and I expected a shower of hot ejected cartridge cases from his M16 on my shoulder. Instead I felt a small object strike me as his weapon suffered a stoppage caused by a separated case, where the base of the fired cartridge case detaches and is ejected, leaving most of the case jammed in the weapon's breech and halting the weapon's functioning. Fortunately, either Bob's single shot or my burst killed the escaping man.

The M60 machine gun, manned by Private Robbie Arnold, and the small group above us brilliantly added their weight of fire to ours, particularly into the two lower huts containing we knew not what. One VC tried to exit to our lower left but was quickly dealt with by Midge, my signaller. After this we had no further targets as the occupants of the two lower huts decamped to the north and downhill in what must have been a practised drill. Unfortunately for them, they immediately entered Dennis's killing ground at short range. A sustained fusillade by the two M60s and rifles of his group quickly sealed their fate. In the shortest time, their quiet rainsoaked haven had become a charnel house. The engagement had unfolded 
exactly as Dennis had planned. Every member had played his part with the patient stealth, iron nerve and ruthless discipline and confidence needed for success in this kind of very close combat.

The nervous tension and silence that followed the deafening noise gave way to the need to report the contact to 5 RAR HQ. Dennis reported the initial details of the contact on his radio net to Paul Greenhalgh and, turning the volume up on my radio, Midge provided our battery commander, Major Neville Gair, with an update of our location and a brief report on the situation. Since we were unsure what lay above us, Dennis agreed that Bob Ziemski's section should neutralise the booby-trapped rifles protecting the track leading uphill from the encampment and secure the approach from that direction. He then reorganised his whole platoon on the high ground on the northern side of the encampment and completed his detailed radio report of the action. At 1630 hours, because of our distance from the rest of D Company, the difficult terrain and the short amount of remaining daylight, we were ordered to secure all enemy weapons, ammunition and documents and return to D Company. A full search of the installation and burial of enemy dead would be conducted the next day. During this pause I busied myself by plotting the route we would follow back to D Company.

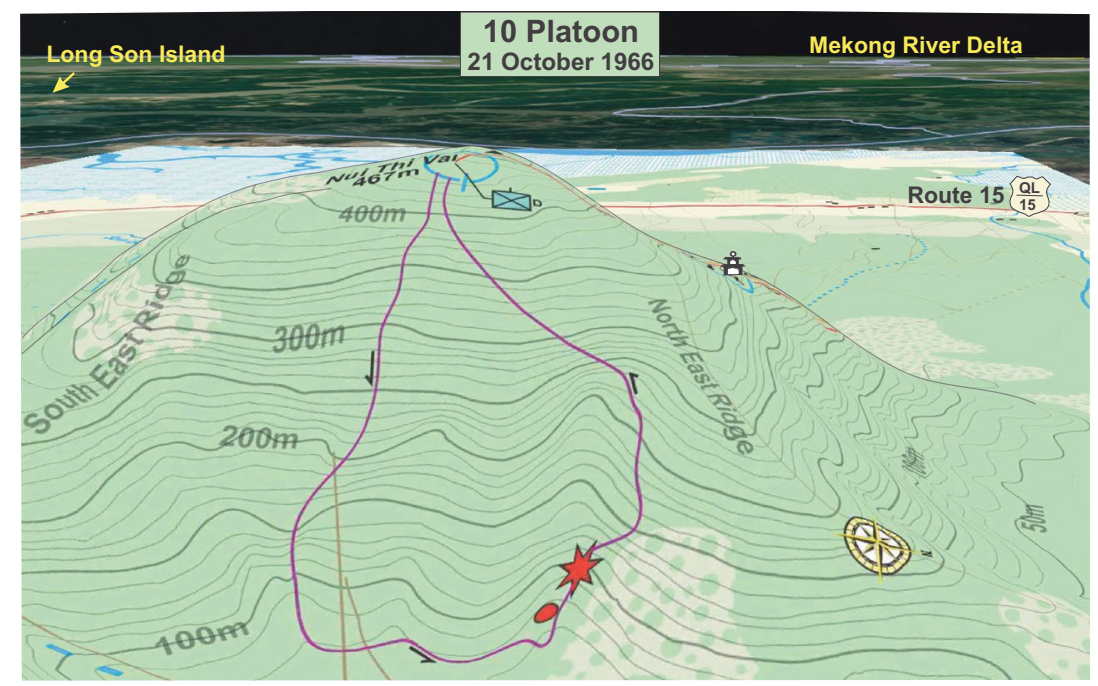

Map 13A: 10 Platoon attack: 21 October 1966.

Source: Designed by Ron Boxall and produced by Alan Mayne from circa 1966 US military maps provided by Bruce Davies. 
In the interest of mobility in very difficult terrain we were patrolling without our full load-carrying equipment. We had to use toggle ropes to tie enemy weapons into small bundles to enable them to be carried with minimal hindrance. The light was already beginning to fade, as indeed was the sustained adrenaline rush and elation we had just experienced, as we clambered from escarpment to escarpment while trying to stick to the return route we had planned. Just after last light, and with waning confidence in our map reading, the welcome 'thumbs up' signal was passed back from our forward section and we passed into D Company's perimeter.

During that night the enemy encampment was engaged with artillery in case other VC elements tried to recover materiel from the site. The next day the whole of D Company returned to the encampment to search it thoroughly, bury the enemy dead and destroy the installation. My initial assessment of the difficulty of getting artillery fire into the encampment proved correct - overnight, rounds had fallen all around the narrow re-entrant, but none fell onto the installation itself. Ten enemy had died at our hands. We later heard that another had escaped but shortly afterwards surrendered at Duc Thanh, many kilometres away to the north-east.

\section{Max Carroll}

The single $\mathrm{VC}$ who escaped from this contact surrendered himself several days later to the ARVN at Duc Thanh and confirmed, under interrogation, that the group which 10 Platoon had attacked was part of the Chau Duc District Company. The subsequent D Company search of the area of the 10 Platoon attack discovered a quantity of clothing, a further cache of rice, packs of documents, medical supplies and several unserviceable weapons.

B Company's time in the ambush role had been as unproductive as that of D Company, so on 23 October 1966 they lifted their ambushes and, together with C Company, proceeded to allotted search areas on Nui Toc Tien. While moving, B Company sighted three VC at a considerable distance and engaged them with artillery fire with unknown results. The search of Nui Toc Tien over the next two days yielded little except for B Company's find of a platoon-sized camp, several weeks old, with some shallow graves close by. 
While this Nui Toc Tien search was proceeding, D Company was continuing their similar task on the eastern slopes of Nui Thi Vai, again with little further result. At the same time, the north-west spur of Nui Thi Vai was being searched by A Company, the assault pioneers and our supporting sappers, with some useful finds being made. By 25 October 1966 we considered that the whole area of operations had been very thoroughly worked over and it was decided to terminate Operation Queanbeyan on the next day. The battalion had been continuously in the field for 21 hard days, spread over three consecutive operations. Our men, while still alert and effective, were tired.

It was expected that, at some time after our departure, the VC would move back to Nui Thi Vai, which had been an important base and sanctuary for them for a very long time. It was impossible to destroy the rocky structure of the mountain and its caves. However, we did what we could and made what was left of the caves, tunnels and the surrounding areas uninhabitable by seeding them with long-lasting tear gas crystals. We destroyed all surface installations with explosives.

A and D Companies linked up with BHQ at the pagoda during the afternoon of 25 October 1966 ready to fly out next morning. The helicopter lift of A Company and BHQ, less the Tactical Command Group, took place between 0645 and 0945 hours. The pagoda LZ was small and could only take one Iroquois at a time. B and C Companies swept south from their overnight harbours near Nui Toc Tien, to link up with armoured personnel carriers at an assembly area near Route 15, which had been secured by a 6 RAR platoon from the FSB. On their way to the assembly area, B Company apprehended a VC suspect, who had some explaining to do back at 1 ATF about why he had been where he was when captured. He was lucky he had not been shot. B and C Companies then moved back to Nui Dat between 1430 and 1530 hours, while the airlift of D Company and BHQ Tac (Tactical Headquarters) took place simultaneously. The FSB then moved back to Nui Dat between 1600 and 1700 hours.

What had we achieved? The operation was considered successful. We had discovered a large, occupied VC base area, with numerous above ground installations and caches, and an extensive multi-layered cave and tunnel system used for accommodation, storage of valuable documents, explosives, ammunition and equipment, as well as concealing many 
effective fire positions. All that we found had been destroyed or rendered untenable. We had also killed, wounded and dispersed VC elements occupying the hills, and found items of high intelligence value. We had hurt and disrupted the VC and it would take them much time and effort to recover, which gave us hard-earned satisfaction. We mourned our dead and felt for the seriously wounded who were evacuated to Australia. The other wounded recovered in-country and then rejoined us. We all appreciated that we were only halfway through our tour of duty and had another six months to go with many more operations to come, and it was a case of just getting on with the job. While there was little time for personal reflection, the essential post-operational analyses were carefully done, as after each operation, to evaluate our actions and procedures, always with the intent of improving our performance.

\section{Editors' conclusion}

It is appropriate to note that several gallantry awards were made for actions in the clearing of Nui Thi Vai and they appear among those listed in Appendix A. In those days, the British Honours and Awards system was used by Australia and it was normal for awards not cited as 'Immediate' to be promulgated several months after the event. When finally announced, they were received with much satisfaction and approval by the battalion. 5 RAR's determined incursions into the enemy's long-held sanctuary of Nui Thi Vai, soon after the Battle of Long Tan, served notice that the arrival of 1 ATF confronted him with a new opponent in Phuoc Tuy who was able to detect and contest his tenure of any piece of terrain. For the battalion, Operation Queanbeyan marked the point when it had found its measure as an Australian infantry battalion, liked what it found and moved forward with unalloyed confidence in its men and its methods. 
This text is taken from Vietnam Vanguard: The 5th Battalion's Approach to Counter-Insurgency, 1966, edited by Ron Boxall and Robert O'Neill, published 2020 by ANU Press, The Australian National University, Canberra, Australia.

doi.org/10.22459/VV.2019.07 